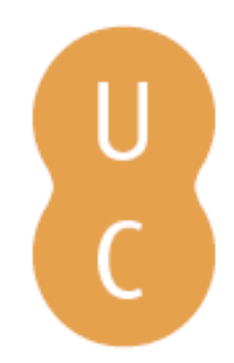

\title{
nommalina
}

\section{Abordagem geográfica dos riscos associados ao transporte ferroviário: os grandes acidentes ferroviários no Mundo, na Europa e em Portugal}

Autor(es): $\quad$ Fernandes, Ricardo

Publicado por: Imprensa da Universidade de Coimbra

URL

persistente: URI:http://hdl.handle.net/10316.2/41807

DOI: $\quad$ DOI:https://doi.org/10.14195/978-989-26-1386-4_1

Accessed : $\quad$ 26-Apr-2023 12:34:40

A navegação consulta e descarregamento dos títulos inseridos nas Bibliotecas Digitais UC Digitalis, UC Pombalina e UC Impactum, pressupõem a aceitação plena e sem reservas dos Termos e Condições de Uso destas Bibliotecas Digitais, disponíveis em https://digitalis.uc.pt/pt-pt/termos.

Conforme exposto nos referidos Termos e Condições de Uso, o descarregamento de títulos de acesso restrito requer uma licença válida de autorização devendo o utilizador aceder ao(s) documento(s) a partir de um endereço de IP da instituição detentora da supramencionada licença.

Ao utilizador é apenas permitido o descarregamento para uso pessoal, pelo que o emprego do(s) título(s) descarregado(s) para outro fim, designadamente comercial, carece de autorização do respetivo autor ou editor da obra.

Na medida em que todas as obras da UC Digitalis se encontram protegidas pelo Código do Direito de Autor e Direitos Conexos e demais legislação aplicável, toda a cópia, parcial ou total, deste documento, nos casos em que é legalmente admitida, deverá conter ou fazer-se acompanhar por este aviso. 
IMPRENSA DA UNIVERSIDADE DE COIMBRA

COIMBRA

UNIVERSITY

PRESS
LUCIANO LOURENÇO (COORD.)

ALCAFACHE

30 ANOS DEPOIS

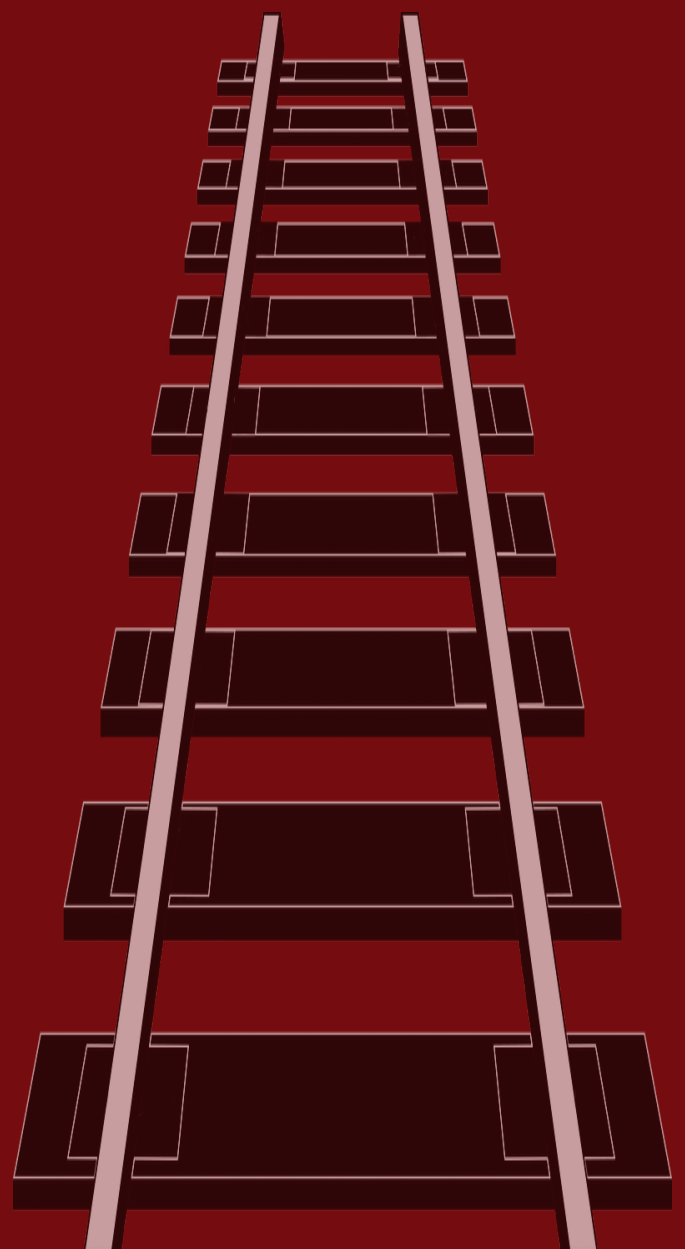




\author{
ABORDAGEM GEOGRÁFICA DOS RISCOS \\ ASSOCIADOS AO TRANSPORTE FERROVIÁRIO: \\ OS GRANDES ACIDENTES FERROVIÁRIOS NO \\ MUNDO, NA EUROPA E EM PORTUGAL \\ GEOGRAPHICALAPPROACH OF THE RISKS \\ ASSOCIATED WITH THE RAILWAY: MAJOR RAILWAY \\ ACCIDENTS IN THE WORLD, EUROPE \\ AND PORTUGAL
}

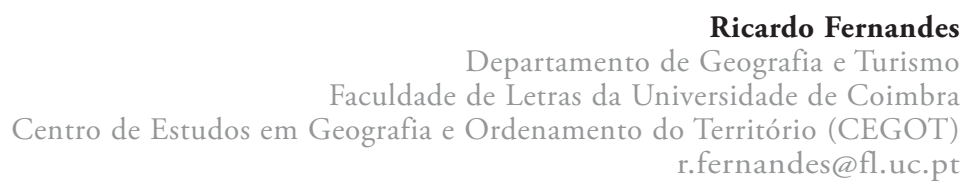

Sumário: A dimensão geográfica da análise dos riscos associados ao transporte ferroviário é central na perceção dos diferentes atores envolvidos neste tipo de cenários de catástrofe e numa lógica de prevenção. O principal objetivo é analisar, numa perspetiva geográfica, alguns dos grandes acidentes ferroviários no Mundo, na Europa e em Portugal. Partindo da identificação das principais ocorrências, procura-se perceber a correlação dos acidentes identificados com os níveis de impacto das catástrofes e com a sua dimensão territorial, identificando diretrizes para uma discussão do risco do transporte ferroviário.

Palavras-chave: Riscos tecnológicos, transporte ferroviário, acidentes ferroviários, mundo, Portugal. 


\begin{abstract}
The geographical dimension of the risk analysis associated with railway is central in the perception of the different actors involved in this type of disaster scenarios and in a logic of prevention. The main goal is to analyze, from a geographic perspective, some of the major railroad accidents in the world, Europe and Portugal. Starting from the identification of the main incidents, it is sought to understand the correlation of the accidents identified with the disaster impact level and its territorial dimension, identifying the guidelines for a discussion on rail risk.
\end{abstract}

Keywords: Technological risks, railway, rail accidents, world, Portugal.

Transporte e acidentes ferroviários. A Geografia e a perceção das causas/consequências e risco(s)

Riscos associados ao transporte ferroviário: enquadramento e bases de
concetualizaçáo inicial

A dinâmica dos transportes e os seus impactes na estrutura espacial são centrais para as discussóes contemporâneas, caracterização das suas redes, identificação de orientações para a organização, planeamento e gestão de modos/ infraestruturas de transporte e para a perceção (geográfica) do risco relacionado (Haggett, 2001; Bavoux, 2005; Knowles et al., 2007; Rodrigue et al., 2013). Se, por um lado, em contexto de catástrofe ferroviária, se podem identificar várias condiçôes/causas de índole técnica (que podem ser comuns a diferentes contextos espaciais e, até, a outros modos de transporte), por outro, surgem elementos que têm uma correlação com condições de ordem territorial e humana.

Considerando o caso específico do transporte ferroviário, a dimensão territorial e/ou geográfica é essencial para uma análise do risco e dos acidentes/ catástrofes (Hall, 1992; Semmens, 1994; Bibel, 2012; Haine, 2012; Rodrigue 
et al., 2013; Richards, 2015). Neste sentido, este tipo de análise poderá explicar, de forma mais efetiva, as disparidades e variaçóes de suscetibilidade, probabilidade e vulnerabilidade associadas aos riscos do transporte ferroviário. Tendo presente diferentes fatores geográficos de contexto (antrópicos e/ou naturais, dependendo do quadro territorial em causa), realidades socioeconómicas e demográficas, bem como dinâmicas intrínsecas aos níveis tecnológicos dos atores envolvidos, podem ser identificadas diferentes perceçóes deste risco e diversas traduçôes em cenário de acidente (Haine, 2012; Rodrigue et al., 2013; Lourenço, 2014; Richards, 2015).

A presente leitura, tendo em conta que náo pretende realizar uma análise da dimensão técnica, é importante na abordagem estatística e geográfica inicial que permita determinar alguns elementos associados à reconstruçáo de conceitos pouco presentes na literatura científica (riscos associados aos transportes). Num contexto de uma pouco expressiva exploração teórico-prática do conceito de risco associado ao transporte ferroviário, torna-se difícil defini-lo de forma linear. A reduzida base concetual e aplicada existente empola a relatividade/ complexidade da definiçáo do conceito, dos seus critérios e enquadramento (condicionado pela especificidade deste tipo de acidentes). Pese embora se identifiquem alguns estudos no quadro de riscos "naturais", "mistos" e "tecnológicos", apenas na última categoria se revelam algumas notas relativamente aos transportes (abordagem aos riscos do "transporte de matérias perigosas" - por exemplo modelos analíticos e espaciais como o Aloha e o Wiser).

A importância de se produzir conhecimento no domínio dos riscos associados aos transportes (e acidentes), nomeadamente no caso do ferroviário, acentua a necessidade de cruzamento concetual prévio com a construçáo teórica de outros tipos de riscos mais estudados (p.e. os naturais). Independentemente de não se perseguir esse objetivo, é necessário enquadrar a perceção do risco com base em diferentes modelos concetuais de risco (mais genéricos) adaptando-os, mesmo que de forma relativa e complexa, ao transporte ferroviário.

Considerando diferentes abordagens, podemos definir risco(s) associado(s) ao(s) transporte ferroviário como o conjunto das "probabilidades de ocorrência de um processolação perigoso (acidente ferroviário) e a respetiva estimativa das 
suas consequências" (Hall, 1992; Semmens, 1994; Bibel, 2012; Haine, 2012; Rodrigue et al., 2013; Richards, 2015). À semelhança de outros tipos de "risco", estas consequências podem ser (direta ou indiretamente) infligidas sobre pessoas, bens ou ambiente, expressas em danos corporais (feridos el ou mortes) e/ou prejuízos materiais (nas composiçóes, na infraestrutura ferroviária, nos terminais, entre outros). No caso específico dos transportes, sublinhamos a centralidade de consequências funcionais e logísticas (tempos de espera, inviabilização temporária e/ou definitivas de movimentos por via ferroviária, entre outros) (fig. 1).

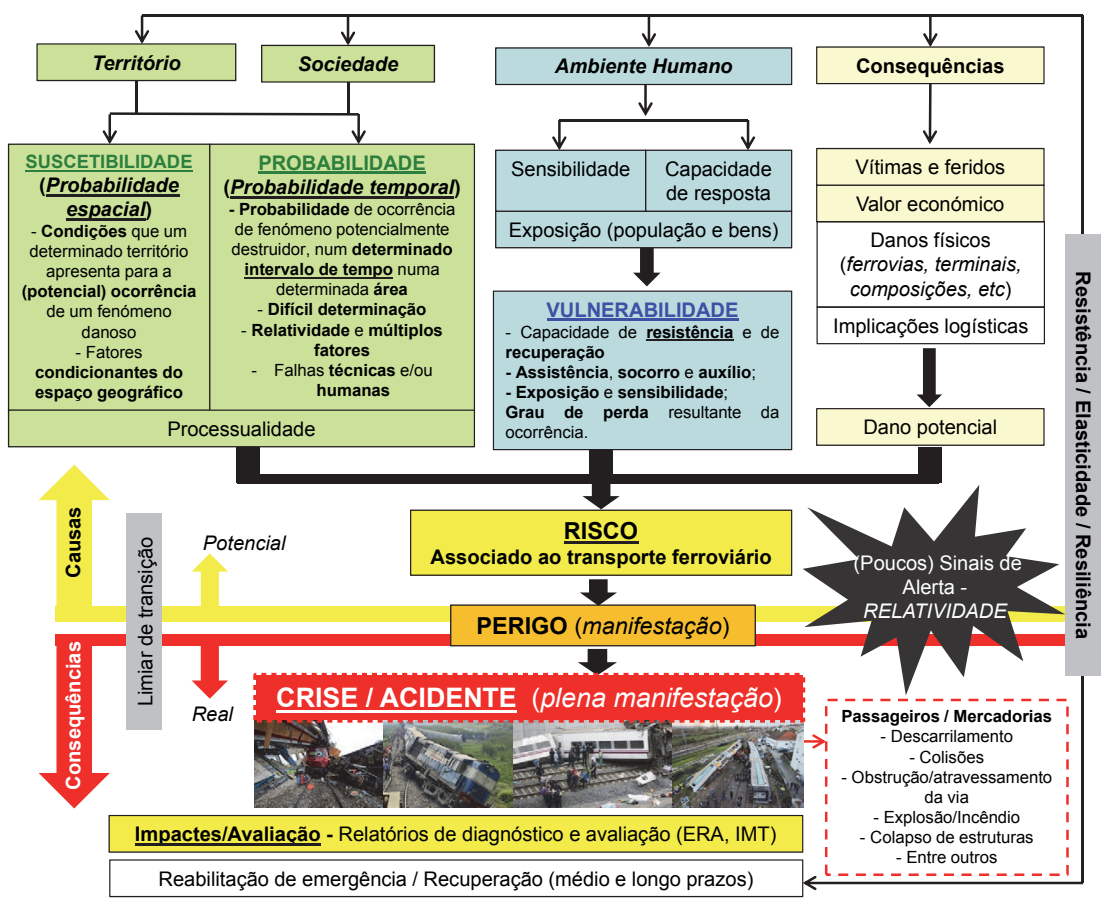

Fig. 1 - Adaptação de modelo usado para análise de manifestações de risco - representação das suas principais componentes: risco-perigo-crise (Baseado em Lourenço, 2014).

Fig. 1 - Adaptation of the model used for risk analysis manifestations - representation of its main components: risk-hazard-crisis (Based on Lourenço, 2014). 
Tendo em conta a especificidade, relatividade e difícil determinação deste tipo de riscos, devem considerar-se os conceitos de suscetibilidade, probabilidade e vulnerabilidade, enquadrados, analisados e medidos de uma forma mais intangível (quando comparados, por exemplo, com os riscos de índole natural). No contexto dos elementos de "território e sociedade", surge o conceito de suscetibilidade que se refere às condiçôes que um determinado território apresenta para a (potencial) ocorrência de um fenómeno danoso. Incorporando uma probabilidade espacial e reunindo os fatores condicionantes do espaço geográfico, é de difícil determinação pois está intimamente ligado a elementos infraestruturais, níveis de desenvolvimento (técnico/tecnológico) dos transportes, bem como aos recursos humanos e intensidade/densidade de fluxos.

O conceito de probabilidade (temporal) é de ainda maior complexidade e relatividade quanto à sua determinaçáo, referindo-se à probabilidade de ocorrência de um fenómeno potencialmente danoso (acidente ferroviário) num determinado intervalo de tempo e numa determinada área. Tendo em conta que neste caso específico existem inúmeros fatores que dependem de elementos técnicos e/ou humanos, a identificação da probabilidade é subjetiva e dificilmente enquadrada em termos aplicados/operacionais. $\mathrm{O}$ conceito de vulnerabilidade e, neste contexto, mais mensurável, referindo-se à capacidade de resistência e de recuperação de um acontecimento danoso. A vulnerabilidade incorpora o nível de capacidade de assistência, socorro e auxílio (medida pelo número, qualidade e eficácia/eficiência dos meios e a sua intervenção específica) e considera os elementos (mais subjetivos) de exposição ao fenómeno, sensibilidade e determinação do grau de perda da ocorrência.

Paralelamente, é importante sublinhar que a determinação de consequências ao nível do número de feridos, mortes, impactes económicos e/ou logísticos, é essencial para a avaliação do risco (Bibel, 2012; Haine, 2012; Rodrigue et al., 2013; Richards, 2015). Se a montante a determinação do dano potencial é importante, a jusante, na perspetiva de um cenário de "pós-acidente", os processos de diagnóstico e avaliação associados a processos de recuperação 
de uma plena manifestação do risco, são essenciais para que se consiga determinar o risco e melhorar as performances de auxílio, socorro e as condiçóes infraestruturais, técnicas e humanas.

Acidentes ferroviários: alicerces para uma matriz de enquadramento e definição

Independentemente da importância da concetualização do risco associado ao transporte ferroviário, a tónica recairá pela perspetiva dos acidentes ferroviários (definição, dinâmicas, causas/percursores e principais tipos de acidentes). Num primeiro momento e tendo como referência a Geografia dos Transportes, acidente (no quadro dos transportes) pode ser considerado uma "ocorrência que envolve danos a pessoas (ferimentos elou morte) elou à infraestrutura fisica" (Rodrigue et al., 2013). Muitas das vezes traduz "imprevistos quanto à sua natureza, dimensão, extensão e probabilidade". Pode traduzir pouca (ou inexistente) avaliaçáo/preparação da potencial ocorrência e refletir lacunas na determinaçáo e/ou gestáo de risco(s) associado(s) (imprevisibilidade). De forma transversal a todas as áreas, esta plena manifestação do risco, reflete custos (diretos e/ou indiretos) materiais, imateriais, humanos, logísticos, funcionais, entre outros (Rodrigue et al., 2013).

Considerando um acidente ferroviário uma ocorrência que envolve uma ou mais composiçôes durante a sua operação nas ferrovias e que implica danos (materiais, imateriais, económicos/logísticos e/ou humanos), existem um conjunto de dinâmicas que devem ser consideradas para a análise deste tipo de acidentes e, consequentemente, centrais para determinação dos riscos associados (Hall, 1992; Bibel, 2012; Haine, 2012; Rodrigue et al., 2013; Richards, 2015). Para que se analisem acidentes ferroviários numa perspetiva geográfica, deve ter-se em conta que estes acontecimentos ocorrem na sequência de processos complexos e relativos de índole técnica e humana, sendo as falhas (associadas aos modos e meios de transporte, infraestruturas, terminais e sistemas de gestáo e ao controlo e segurança) centrais para a sua perceçáo. Associados à ocorrência de acidentes ferroviários podem ser identificados outros elementos essenciais para 
a sua perceção, como o aumento da mobilidade e a complexidade, densidade e intensidade dos fluxos de transporte.

Paralelamente, temos que considerar outras dinâmicas intrínsecas ao nível tecnológico dos atores e territórios (densidade, intensidade dos fluxos ferroviários e diferentes perceçóes do risco e acidente). Para a interpretação e prevenção dos acidentes ferroviários, observa-se uma preponderância dos fatores geográficos de contexto (antrópicos e/ou naturais, materiais e/ou imateriais, dependendo do contexto territorial), das realidades demográficas e socioeconómicas e das diversas questóes territoriais (que criam diferentes condicionantes, especificidades e disparidades). Um outro grupo de elementos a considerar, está associado à prevenção das ocorrências e à segurança, gestão e auxílio/socorro em contexto de acidente. A posteriori, como elementos de diferenciação territorial, surge a capacidade de "ajustamento" ao dano potencial, bem como a resistência e recuperação às perdas. Existem outras dinâmicas que se relacionam, mesmo que pontualmente, à ocorrência (mais ou menos intensa) de acidentes ferroviários, exemplos de "eventos" de pirataria, terrorismo, conflitos, choques económicos e/ou políticos, que podem despoletar ocorrências gravosas.

Com base nos diferentes elementos teóricos e empíricos apontados, tendo em conta os diversos contextos espaciais e que estes podem ocorrer simultaneamente, podem ser elencados diferentes tipos de acidentes ferroviários: descarrilamento, colisão (entre composições/comboios; com automóveis e/ou edificações, após descarrilamento), obstrução elou atravessamento da via, atropelamento (mesmo sendo comum, é mais específico quanto à génese), bem como outros menos comuns, casos de acidentes por explosão, incêndio elou eletrocussão, colapso estrutural de infraestruturas (p.e. pontes, túneis, carris, vias permanentes, entre outros), fatores de cariz natural (indiretos - podem despoletar os restantes tipos), entre outros (mais específicos e/ou pontuais).

Os diferentes tipos de acidentes ferroviários podem, em paralelo, ser cruzados com diferentes causas/percursores destes acontecimentos danosos, numa perspetiva humana/antrópica, técnica, natural e mista (TABELA I). À semelhança dos diferentes tipos de acidentes, as suas causas podem ser igualmente transversais, mútuas e múltiplas, sendo que um acidente poder ser explicado, ao mesmo tempo, por fatores humanos, técnicos e naturais. 
TABELA I - Principais causas/percursores dos acidentes ferroviários.

TABLE I - Main causes / precursors of railway accidents.

\begin{tabular}{|c|c|c|}
\hline \multicolumn{3}{|c|}{ Principais causas/percursores dos acidentes ferroviários } \\
\hline Humanas/Antrópicas & Técnicas & Naturais (indiretas) \\
\hline $\begin{array}{l}\text { - Erro humano generalizado; } \\
\text { - Desrespeito por sinalização, barreiras } \\
\text { e outros; } \\
\text { - Excesso de velocidade; } \\
\text { - Falhas nas manobras na via e/ou } \\
\text { terminal; } \\
\text { - Desrespeito por indicaçóes de gestấo } \\
\text { de tráfego; } \\
\text { - Atos de terrorismo, conflitos e } \\
\text { outros; } \\
\text { - Outras causas/ percursores. }\end{array}$ & $\begin{array}{l}\text { - Deterioração das estruturas das ferrovias } \\
\text { e/ou equipamentos e veículos associa- } \\
\text { dos (comboios e outros); } \\
\text { - Falhas de equipamentos de sinalização, } \\
\text { segurança, barreiras, entre outros; } \\
\text { - Falhas de equipamentos de gestão de } \\
\text { tráfego (infraestruturas, software, } \\
\text { comunicaçōes, entre outros); } \\
\text { - Deficiência/avaria na composiçáo; } \\
\text { - Problemas nas infraestruturas e/ou } \\
\text { terminais; } \\
\text { - Outras causas/ percursores. }\end{array}$ & $\begin{array}{l}\text { - Nevoeiro; } \\
\text { - Terramotos/sismos; } \\
\text { - Deslizamento de terras; } \\
\text { - Instabilidade de ver- } \\
\text { tentes; } \\
\text { - Avalanches; } \\
\text { - Inundaçôes; } \\
\text { Outros elementos climá- } \\
\text { ticos e/ou associados ao } \\
\text { estado de tempo; } \\
\text { - Outras causas/ percur- } \\
\text { sores. }\end{array}$ \\
\hline \multicolumn{3}{|c|}{ Mistas } \\
\hline $\begin{array}{l}\text { Desmoronamentos, colapsos e outros } \\
\text { çăo, segurança, barreiras, }\end{array}$ & 11 & $\begin{array}{l}\text { bem como nos de sinaliza- } \\
\text { os), entre outras; }\end{array}$ \\
\hline
\end{tabular}

\section{Perspetiva geográfica dos acidentes ferroviários no Mundo, Europa e em Portugal. Principais dados e exemplos}

\section{Aspetos metodológicos}

O principal objetivo da presente investigação é analisar estatística e geograficamente os acidentes ferroviários a diferentes escalas (Mundo, Europa e Portugal), permitindo realizar uma espacializaçáo das diferentes ocorrências e uma leitura espacial dos acidentes no sentido da construção do conceito de risco e das suas disparidades territoriais.

Para a realizaçáo dessa análise construiu-se uma base de dados dos principais acidentes ferroviários no Mundo. Tendo em conta a dispersão de informação (por vezes ausência e/ou cariz incompleto), realizou-se um cruzamento de um conjunto de informaçáo (complexa, dispersa e relativa e, mesmo assim, refletindo a falta de algumas ocorrências/acidentes). Considerando para a análise os acidentes ferroviários com vítimas mortais, existiu a necessidade de consultar/ utilizar um conjunto alargado de fontes, numa perspetiva de recolha temporal e espacial, integrando todas as ocorrências identificadas (recolha online, periódi- 
cos, jornais, revistas, Wikipédia, observatório Lumo Transport, European Railway Agency - relatórios de segurança e sítio internet - e em algumas publicaçóes, por exemplo, Edgar Haine, "Railway Wrecks").

Em termos metodológicos, a construção da base de dados (principal ferramenta da presente análise), integrou diferentes campos de recolha e informaçáo/ atributos: data da ocorrência (dia, mês e ano, mesmo que em alguns casos aproximado); fonte (quando aplicável); localização (específica, concelho, país e continente); coordenadas geográficas (georreferenciaçáo/cartografia); tipo de acidente (quando determinado); principal causa e outras causas (quando determinadas); número de mortes e feridos (quando determinados). Independentemente de se terem realizado alguns testes estatísticos e utilizado algumas metodologias de tratamento de dados mais complexas (sem resultados significativos), a análise foi centrada na leitura simples da informação, na criação de tipologias e no recurso a tabelas dinâmicas para tratamento estatístico, gráfico e cartográfico.

\section{Principais acidentes no Mundo e na Europa}

Partindo dos atributos recolhidos para os acidentes identificados na base de dados e no sentido de se caraterizar o padrão espacial e frequência das ocorrências, consideraram-se apenas os acidentes com mortes. Esta perspetiva multiescalar permite-nos enquadrar Portugal e perceber a dimensão da existência de ocorrências a diferentes escalas, tentando perspetivar os riscos associados ao transporte ferroviário.

Com efeito, foram identificados 429 acidentes ferroviários (com mortes) em cerca de 57 países e num período temporal entre 1865 (data do primeiro acidente identificado) e 2016 (TABELA II). No que se refere às fontes de informação, a principal origem dos dados resultou dos relatórios de segurança da European Railway Agency (ERA) (223 ocorrências) e da publicação de Edgar Haine (2012) (98 ocorrências), logicamente condicionando a sua distribuição espacial e a informação disponível acerca de cada um dos acidentes. Por grandes unidades espaciais, observou-se uma forte preponderância na Europa (81,29\% dos 429 acidentes 
contabilizados - fruto da maior informação da $E R A)$, Ásia (8,55\%), América do Sul $(4,19 \%)$ e África (3,23\%), sendo que Portugal, muito devido à génese das fontes apresenta valores com alguma expressão (18,4\% do total de ocorrências).

Numa perspetiva evolutiva (no período da recolha - 1865 a 2016), observa-se que grande parte dos acidentes ocorreram após 1975 (21,68\% entre 1975 e 1999; $26,11 \%$ de 2000 a 2010; 25,87\% depois de 2010) (fig. 2). Este comportamento está relacionado principalmente como a disponibilidade de informação estatística e técnica a partir dos anos 80 e 90, em detrimento da maior ocorrência de eventos danosos e intensidade dos fluxos ferroviários em alguns territórios. Mesmo que sem tanta expressão, a análise da frequência média mensal dos acidentes é interessante, verificando-se uma maior predominância (mesmo que não muito significativa) da ocorrência nos meses de janeiro $(10,96 \%)$ e entre os meses de Junho e Setembro.

Espacialmente, no quadro da localizaçâo específica dos acidentes ferroviários e da sua contabilizaçáo por país, verificamos que grande parte das ocorrências foram registadas na Europa e em países como Portugal (18,41\% dos acidentes;

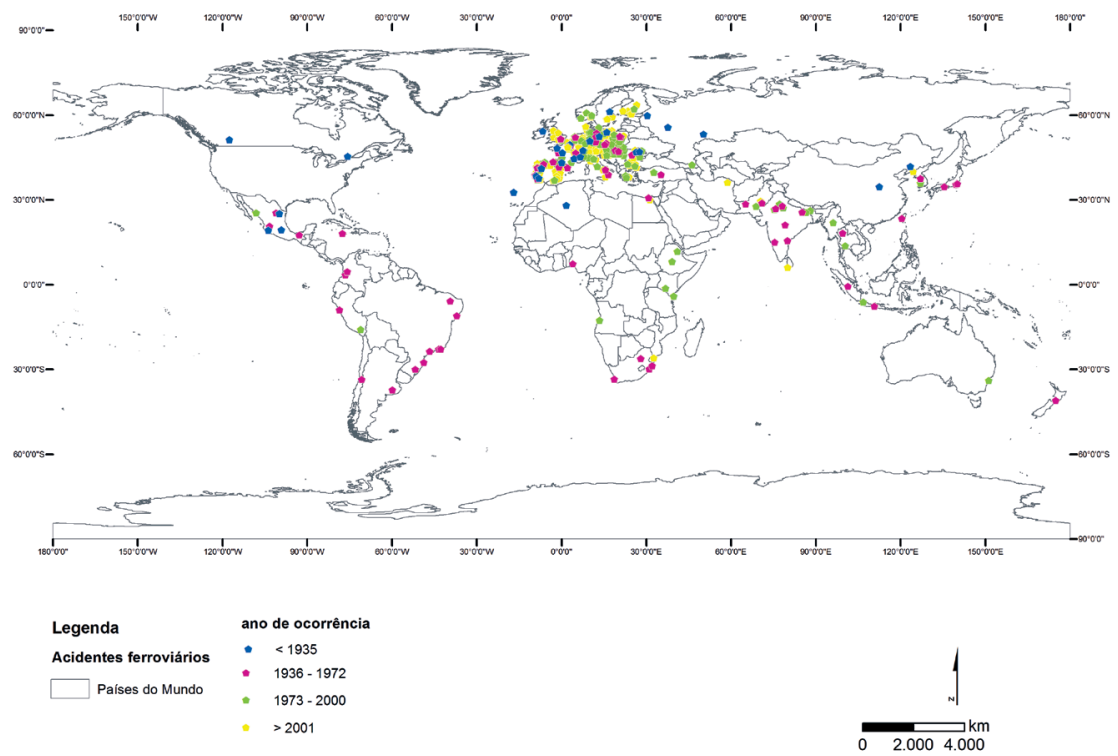

Fig. 2 - Localização dos acidentes ferroviários no mundo, por ano (1865-2016).

Fig. 2 - Location of railway accidents in the world per year (1865-2016).. 
TABELA II - Lista de acidentes ferroviários no mundo (mais de150 mortes) (1865-2016). TABLE II - List of railway accidents in the world (more than 150 deaths) (1865-2016).

\begin{tabular}{|c|c|c|c|c|c|c|c|c|}
\hline No & Ano & Dia & Mês & Localizaçáo & País & Tipo de Acidente & $\begin{array}{l}\mathrm{N}^{\circ} \\
\text { Feridos }\end{array}$ & $\begin{array}{c}\mathrm{N}^{\circ} \\
\text { Mortos }\end{array}$ \\
\hline 1 & 2004 & 26 & Dezembro & Peraliya & Sri Lanka & Descarrilamento & -.. & 1700 \\
\hline 2 & 1981 & 6 & Abril & Bagmati & Índia & Descarrilamento & -.. & 800 \\
\hline 3 & 1917 & 13 & Janeiro & Ciurea & Roménia & Descarrilamento & -.. & 700 \\
\hline 4 & 1981 & 6 & Junho & Mansi & Índia & Descarrilamento & -.. & 608 \\
\hline 5 & 1989 & 4 & Junho & Slobodzinski & Moldávia & $\begin{array}{l}\text { Explosáo/Incêndio/Eletro- } \\
\text { cussáo }\end{array}$ &.- & 607 \\
\hline 6 & 1915 & 22 & Janeiro & Colima & México & Descarrilamento & 250 & 600 \\
\hline 7 & 1989 & 4 & Junho & Asha & Rússia & $\begin{array}{l}\text { Explosáo/Incêndio/Eletro- } \\
\text { cussáo }\end{array}$ & -- & 575 \\
\hline 8 & 1917 & 12 & Dezembro & Modane & França & Descarrilamento & -.- & 540 \\
\hline 9 & 1944 & 2 & Março & Balvano & Itália & $\begin{array}{c}\text { Barreira e Queda/colpaso de } \\
\text { ponte/túnel }\end{array}$ & $\ldots$ & 530 \\
\hline 10 & 1944 & 16 & Janeiro & Torre del Bierzo & Espanha & Colisáo (entre comboios) & -.. & 500 \\
\hline 11 & 1985 & 14 & Janeiro & Arba & Etiópia & Descarrilamento & -- & 450 \\
\hline 12 & 1985 & 13 & Janeiro & Afar & Etiópia & Descarrilamento & -.. & 428 \\
\hline 13 & 1947 & 1 & Julho & Sumatra & Indonésia & Colisáo (entre comboios) & $\ldots$ & 400 \\
\hline 14 & 2002 & 20 & Fevereiro & Cairo & Egipto & $\begin{array}{l}\text { Explosáo/Incêndio/Eletro- } \\
\text { cussáo }\end{array}$ & $\ldots$ & 383 \\
\hline 15 & 1995 & 20 & Agosto & Firozabad & Índia & Colisáo (entre comboios) & -- & 355 \\
\hline 16 & 1995 & 20 & Agosto & Nova Delhi & Índia & Colisáo (entre comboios) & -.. & 350 \\
\hline 17 & 2004 & 18 & Fevereiro & Neyshabur & Iráo & Descarrilamento & -.- & 320 \\
\hline 18 & 1915 & 21 & Junho & MonteMorelos & México & Descarrilamento & 200 & 300 \\
\hline 19 & 1957 & 29 & Setembro & Gambar & Paquistáo & Colisáo (entre comboios) & 150 & 300 \\
\hline 20 & 1994 & 22 & Setembro & Benguela & Angola & Descarrilamento & -.- & 300 \\
\hline 21 & 1999 & 2 & Agosto & Gaisal & Índia & Colisáo (entre comboios) & -.- & 288 \\
\hline 22 & 1939 & 22 & Dezembro & Genthin & Alemanha & Colisáo (entre comboios) & 200 & 231 \\
\hline 23 & 1957 & 29 & Setembro & Ibadane & Nigéria & Descarrilamento & 147 & 225 \\
\hline 24 & 1881 & 22 & Junho & $\begin{array}{l}\text { Cidade do } \\
\text { México }\end{array}$ & México & $\begin{array}{c}\text { Barreira e Queda/colapso de } \\
\text { ponte/túnel }\end{array}$ & 50 & 216 \\
\hline 25 & 1990 & 3 & Janeiro & Sukhur & Paquistáo & Colisáo (entre comboios) & $\ldots$ & 210 \\
\hline 26 & 1972 & 5 & Outubro & Saltillo & México & Descarrilamento & 700 & 208 \\
\hline 27 & 1933 & 23 & Dezembro & Lagny & França & Colisáo (entre comboios) & 300 & 200 \\
\hline 28 & 1949 & 24 & Outubro & Nowydwor & Polónia & Descarrilamento & 200 & 200 \\
\hline 29 & 1935 & 24 & Setembro & Loyang & China & Descarrilamento & 200 & 200 \\
\hline 30 & 2002 & 25 & Maio & Maputo & Moçambique & Descarrilamento & --. & 195 \\
\hline 31 & 1946 & 20 & Março & Aracaju & Brasil & Descarrilamento & 200 & 185 \\
\hline 32 & 1940 & 29 & Janeiro & Osaka & Japáo & Descarrilamento & 400 & 173 \\
\hline 33 & 1957 & 1 & Setembro & Kendal & Jamaica & Descarrilamento & 400 & 173 \\
\hline 34 & 1963 & 9 & Novembro & Yokohama & Japão & Colisáo (entre comboios) & 66 & 162 \\
\hline 35 & 1962 & 3 & Maio & Tóquio & Japáo & Colisáo (entre comboios) & 383 & 160 \\
\hline 36 & 1953 & 24 & Dezembro & Tanhwaie & Nova Zelândia & $\begin{array}{c}\text { Barreira e Queda/colapso de } \\
\text { ponte/túnel }\end{array}$ & -- & 155 \\
\hline 37 & 2004 & 22 & Abril & Ryongchon & Coreia do Norte & Colisáo (entre comboios) & --- & 154 \\
\hline 38 & 1987 & 19 & Outubro & Jacarta & Indonésia & Colisáo (entre comboios) & -- & 152 \\
\hline 39 & 1985 & 11 & Setembro & Alcafache & Portugal & Colisáo (entre comboios) & Vários & 150 \\
\hline 40 & 1992 & 1 & Novembro & Reti & Índia & Colisão (entre comboios) & -- & 150 \\
\hline
\end{tabular}


fontes e mais informação disponível), Alemanha (7,46\%), Hungria (6,99\%), França (6,06\%), Espanha e Polónia (5,13\%), República Checa (4,90\%), Itália (3,50\%), Reino Unido (3,03\%), Índia e Roménia (2,80\%), Brasil e Áustria $(2,33 \%)$, entre outros (TABELA III).

Para além da existência de mais informação e dados em algumas unidades espaciais, esta distribuição poderá estar igualmente associada a uma maior extensão/densidade da rede ferroviária, do número de composiçóes a circular, número de passageiros, toneladas de mercadorias e maior densidade e intensidade dos fluxos e "nós" (alicerçando-se os conceito de probabilidade espacial e temporal).

Partindo da construçáo do conceito de risco associado ao transporte ferroviário, devem considerar-se os danos potenciais e consequências como "drivers" centrais para a sua concetualização. A análise dos acidentes ferroviários na perspetiva das mortes causadas poderá ser importante para se relacionar as ocorrências com as dimensōes da suscetibilidade, probabilidade e vulnerabilidade, percebendo, numa perspetiva geográfica, lógicas de cruzamento entre os eventos, número de mortes e localizaçáo/ contexto territorial. Considerando as mortes, verifica-se uma concentraçáo destes danos na Europa, com uma parte significativa das 22.440 mortes (TABELA III).

Paralelamente a todas estas dinâmicas, a Europa (mesmo que com maior número de acidentes ferroviários) acaba por ter um menor número médio de mortes por acidente. Outras localizaçóes externas ao espaço europeu, mesmo que de forma mais pontual, traduzem a ocorrência de acidentes com número médio de mortes bem mais elevado. Neste contexto, independentemente da informaçáo disponível traduzir um menor número efetivo de ocorrências danosas, o seu contexto territorial e/ou a especificidade gravosa do acidente e a(s) sua(s) causa(s), fez com que existisse um número levado de feridos e mortes (fig. 3 e Tabela II).

Em paralelo à dificuldade em estabelecer um padrão espacial sólido relativamente à distribuição espacial dos acidentes ferroviários e mortes associadas, é importante sublinhar que o carácter aleatório de mortes nos acidentes ferroviários tem uma expressão mais relacionada com a singularidade $\mathrm{da}(s)$ ocorrência(s), as condiçóes específicas da localização, dos movimentos, das infraestruturas e da densidade de utilização/circulação. No fundo, as consequências diretas nas vidas humanas poderão estar associadas a acontecimentos e fatores muito pontuais que acentuam a centrali- 
TABELA III - Acidentes ferroviários no mundo, por país e número de mortes (1865-2016). TABLE III - Railway accidents in the world, by country and number of deaths (1865-2016).

\begin{tabular}{|c|c|c|c|c|c|c|c|c|c|}
\hline \multicolumn{10}{|c|}{ Acidentes ferroviários e mortes associadas no Mundo } \\
\hline \multirow{2}{*}{ Pais } & \multicolumn{2}{|c|}{ MORIES } & \multicolumn{2}{|c|}{ ACID ENIUES } & \multirow{2}{*}{ País } & \multicolumn{2}{|c|}{ MORUES } & \multicolumn{2}{|c|}{ ACIDENIUES } \\
\hline & No & $\%$ & No & $\%$ & & No & $\%$ & No & $\%$ \\
\hline Índia & 3008 & 13,40 & 12 & 2,80 & Turquia & 175 & 0,78 & 3 & 0,70 \\
\hline Sri Lanka & 1700 & 7,58 & 1 & 0,23 & Jamaica & 173 & 0,77 & 1 & 0,23 \\
\hline México & 1509 & 6,72 & 7 & 1,63 & Perú & 162 & 0,72 & 2 & 0,47 \\
\hline França & 1196 & 5,33 & 26 & 6,06 & Nova Zelândia & 155 & 0,69 & 1 & 0,23 \\
\hline Roménia & 1022 & 4,55 & 12 & 2,80 & Coreia do Norte & 154 & 0,69 & 1 & 0,23 \\
\hline Etiópia & 878 & 3,91 & 2 & 0,47 & Suiça & 139 & 0,62 & 2 & 0,47 \\
\hline Brasil & 871 & 3,88 & 10 & 2,33 & Croácia & 127 & 0,57 & 3 & 0,70 \\
\hline Espanha & 847 & 3,77 & 22 & 5,13 & Coreia do Sul & 122 & 0,54 & 3 & 0,70 \\
\hline Rússia & 780 & 3,48 & 5 & 1,17 & Birmânia & 102 & 0,45 & 1 & 0,23 \\
\hline Itália & 732 & 3,26 & 15 & 3,50 & Holanda & 97 & 0,43 & 3 & 0,70 \\
\hline Portugal & 731 & 3,26 & 79 & 18,41 & Tailândia & 89 & 0,40 & 2 & 0,47 \\
\hline Japão & 699 & 3,11 & 5 & 1,17 & Canadá & 83 & 0,37 & 2 & 0,47 \\
\hline Indonésia & 694 & 3,09 & 4 & 0,93 & Austrália & 80 & 0,36 & 1 & 0,23 \\
\hline Alemanha & 618 & 2,75 & 32 & 7,46 & Irlanda & 75 & 0,33 & 1 & 0,23 \\
\hline Moldávia & 607 & 2,70 & 1 & 0,23 & Colômbia & 66 & 0,29 & 2 & 0,47 \\
\hline Paquistáo & 602 & 2,68 & 4 & 0,93 & Suécia & 56 & 0,25 & 5 & 1,17 \\
\hline Polónia & 448 & 2,00 & 22 & 5,13 & Algéria & 50 & 0,22 & 1 & 0,23 \\
\hline Egipto & 411 & 1,83 & 2 & 0,47 & Chile & 49 & 0,22 & 1 & 0,23 \\
\hline Reino Unido & 360 & 1,60 & 13 & 3,03 & Taiwan & 48 & 0,21 & 1 & 0,23 \\
\hline Irão & 320 & 1,43 & 1 & 0,23 & Eslováquia & 41 & 0,18 & 9 & 2,10 \\
\hline Angola & 300 & 1,34 & 1 & 0,23 & Noruega & 40 & 0,18 & 7 & 1,63 \\
\hline República Checa & 280 & 1,25 & 21 & 4,90 & Bélgica & 38 & 0,17 & 7 & 1,63 \\
\hline África do Sul & 259 & 1,15 & 4 & 0,93 & Áustria & 26 & 0,12 & 10 & 2,33 \\
\hline Hungria & 255 & 1,14 & 30 & 6,99 & Bulgária & 25 & 0,11 & 5 & 1,17 \\
\hline Argentina & 253 & 1,13 & 3 & 0,70 & Grécia & 21 & 0,07 & 5 & 1,17 \\
\hline China & 250 & 1,11 & 2 & 0,47 & Finlândia & 16 & 0,07 & 6 & 1,40 \\
\hline Nigéria & 225 & 1,00 & 1 & 0,23 & Eslovénia & 2 & 0,01 & 2 & 0,47 \\
\hline Moçambique & 195 & 0,87 & 1 & 0,23 & Dinamarca & 1 & 0,00 & 1 & 0,23 \\
\hline Quénia & 178 & 0,79 & 2 & 0,47 & Total Geral & 22440 & 100,0 & 429 & 100,0 \\
\hline
\end{tabular}




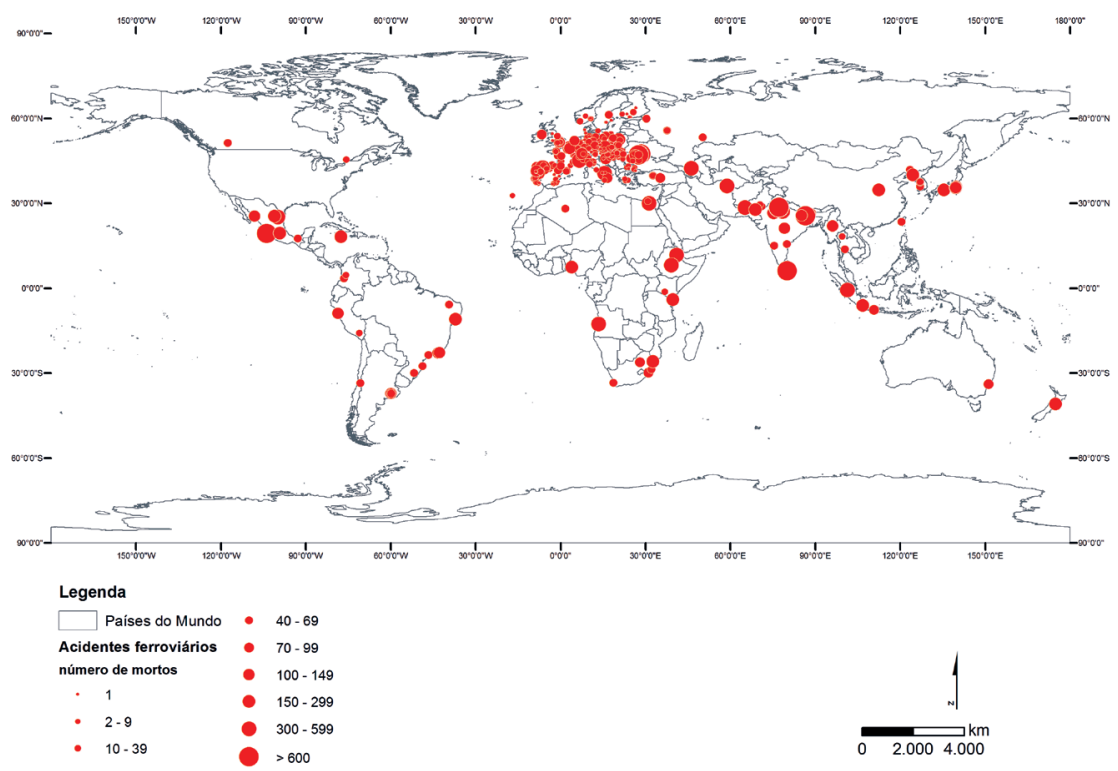

Fig. 3 - Localização dos acidentes ferroviários, por $n^{\circ}$ de mortes (1865-2016). Fig. 3 - Location of railway accidents in the world, by number of deaths (1865-2016).

dade dos acidentes de grande dimensão (mesmo que espacialmente aleatórios), mas com uma tendência para a observação de um maior número médio de mortes em países menos desenvolvidos (lacunas técnicas, infraestruturais, de auxílio e socorro, maiores densidades populacionais e menores capacidades/competências técnicas a montante e/ou a jusante do acidente, bem como na relação direta com catástrofes naturais e ocorrências inesperadas que despoletam o acidente).

Pensando nestes pressupostos e cruzando-os com a evolução do número de mortes nos acidentes ferroviários no mundo, facilmente identificamos ocorrências que contribuem para os quantitativos das mortes sem que haja um padrão espacial predefinido e uma lógica temporal dos acontecimentos (fig. 4).

Uma outra dimensão de análise importante refere-se à abordagem aos acidentes ferroviários por tipo. Dos 429 acidentes identificados no Mundo e tendo em conta todos os elementos e fatores discutidos até ao momento, existe uma predominância de ocorrências relacionadas com colisóes por atravessamos/ obstrução (com cerca de 31,00\% dos eventos), colisão entre comboios (30,54\%), 


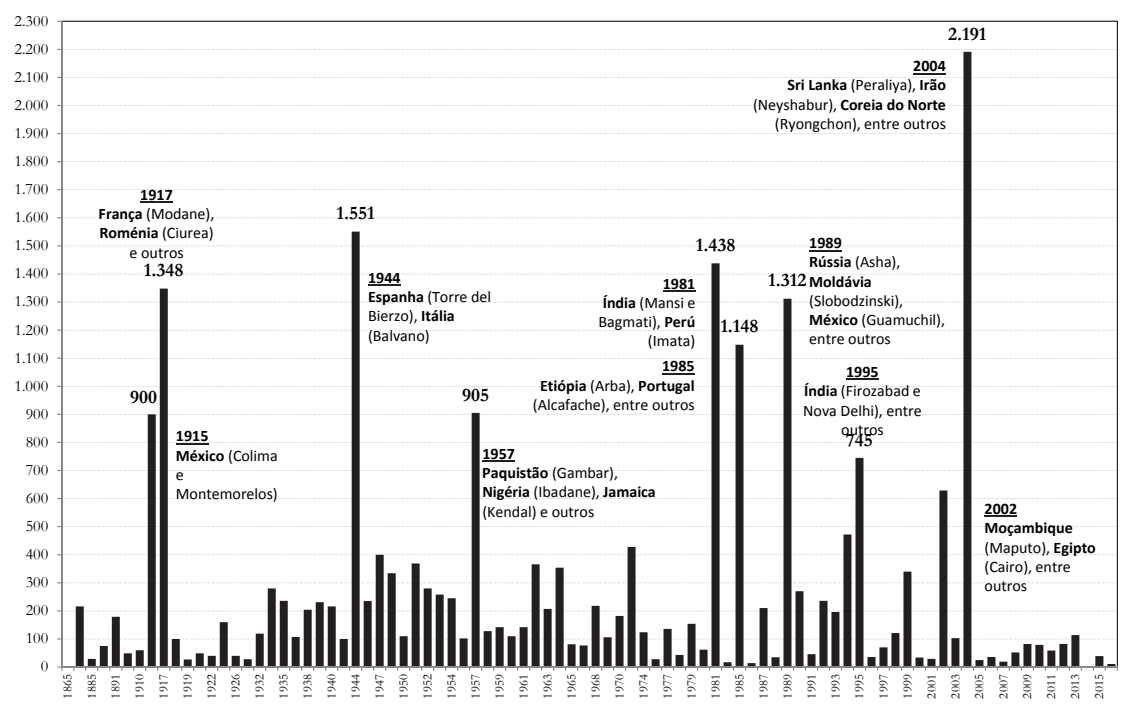

Fig. 4 - Evolução do número de mortes em acidentes ferroviários no mundo, por ano (1865-2016).

Fig. 4 - Evolution of the number of deaths in railway accidents in the world per year (1865-2016).

descarrilamentos (20,05\%) e atropelamentos (12,59\%), sendo que praticamente todos estes se relacionam com causas associadas à maior intensidade dos fluxos e infraestruturas.

Espacialmente, tendo em consideração a maior concentração de informação/ acidentes na Europa, observa-se uma maior diversidade de tipos de ocorrências neste bloco espacial (contudo, refletindo o padrão de tipologia dos valores globais para o Mundo) (fig. 5). Pensando nos restantes territórios, como por exemplo a Ásia, existe uma maior centralidade de colisóes entre comboios, descarrilamentos e explosóes, incêndios e eletrocussão.

Focalizando a análise à escala europeia, não se verificam grandes alteraçóes relativamente ao número de acidentes e distribuição/localização espacial, bem como o impacte nas consequências humanas destas ocorrências (mortes).

À semelhança de dinâmicas anteriores, a localização dos acidentes não traduz (diretamente) um padrão espacial definido e as suas consequências. Considerando o número de mortes, estas dinâmicas estão associadas a acontecimentos pontuais 


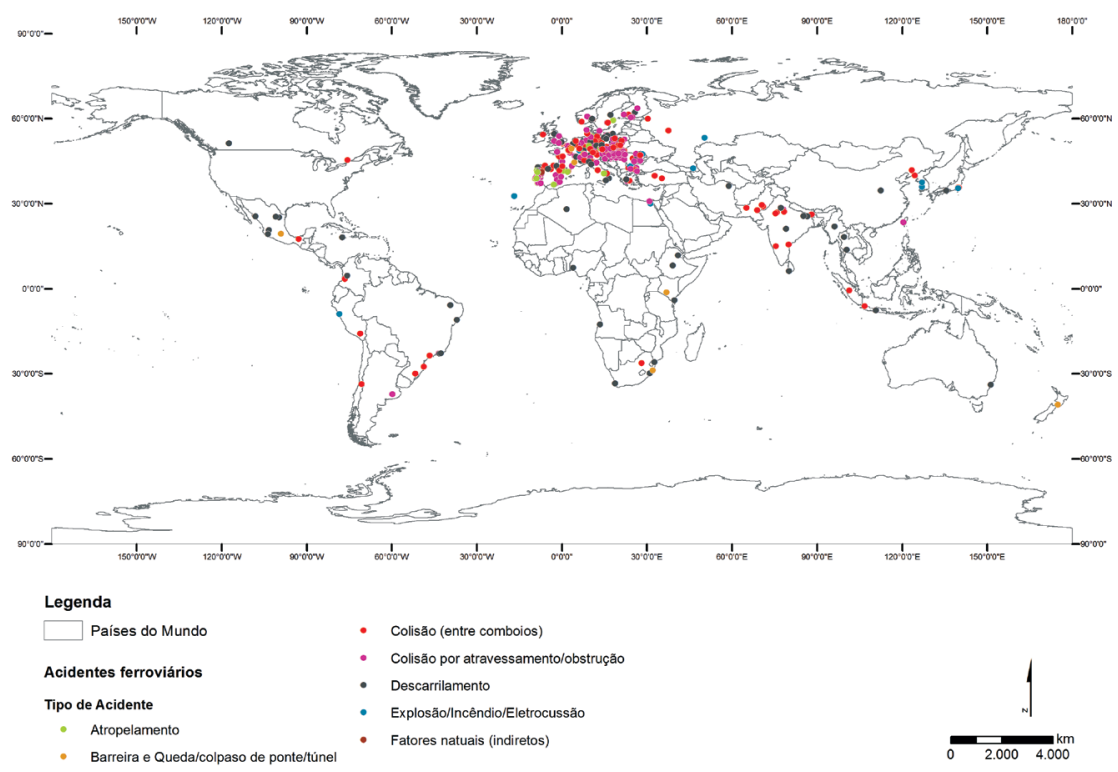

Fig. 5 - Localização dos acidentes ferroviários no mundo, por grande tipo de acidente (1865-2016).

Fig. 5 - Location of railway accidents in the world, by major type of accident (1865-2016).

e de características muito específicas, de que são exemplo os acidentes ferroviários de Santiago de Compostela (Espanha), Ciureia (Roménia), Slobodzinski (Moldávia), Eschede (Alemanha), Alcafache (Portugal), Modane (França), entre outros (fig. 6). Em paralelo, considerando a análise das ocorrências na Europa por grande tipo de acidente ferroviário, sublinha-se a maior diversidade dos eventos face ao seu tipo e à maior correlação com a informação disponível, as intensidades e densidades dos fluxos, infraestruturas e terminais ferroviários nestes territórios (fig. 7).

\section{Geografia(s) dos acidentes ferroviários em Portugal}

Independentemente da abordagem à escala mundial e europeia já ter evidenciado, indiretamente, alguns comportamentos dos acidentes ferroviários em Portugal, torna-se imperativo especificar de forma mais focalizada alguns 


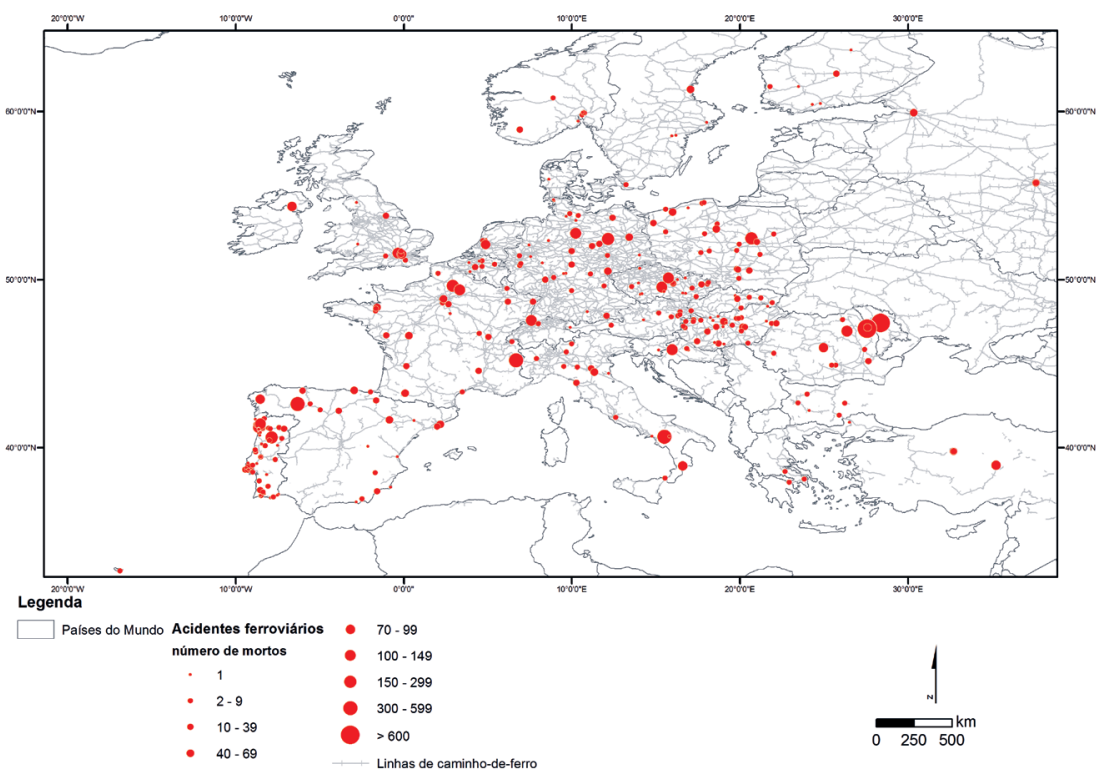

Fig. 6 - Localização dos Acidentes ferroviários na Europa, por no de mortes (1865-2016). Fig. 6 - Location of railway accidents in Europe by number of deaths (1865-2016).

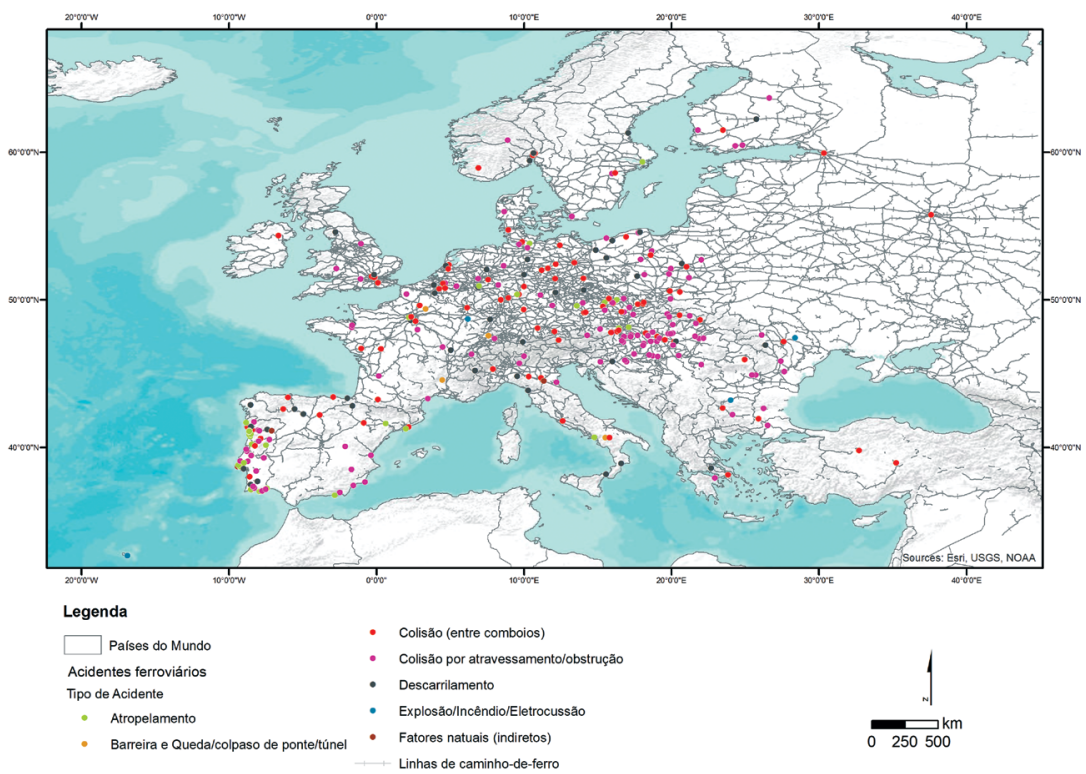

Fig. 7 - Acidentes ferroviários na Europa, por grande tipo de acidente (1865-2016).

Fig. 7 - Railway accidents in Europe by major type of accident (1865-2016). 
dos principais comportamentos. No período considerado foram identificados 79 acidentes ferroviários com mortes (cerca de 18,41\% do total de 429 ocorrências no Mundo), não se verificando, estruturalmente, grandes diferenças ao nível dos padrôes espaciais, tipo de acidentes, causas/percursores. A tendência indica-nos uma maior representatividade de ocorrências pontuais, tendo em conta enquadramentos específicos/aleatórios da localizaçáo espacial dos eventos, causas, consequências e tipo de acidente. Neste contexto, ganham representatividade ocorrências "chave" que, por diferentes razōes, tiveram fortes impactes antrópicos, técnicos, infraestruturais e, até mesmo, naturais nas suas localizaçōes (Alcafache, 1985; Vila Nova de Famalicão, 1964; Custóias, 1964; Póvoa de Santa Iria, 1986; Baião, 2009; entre outros) (TABela IV).

Dos acidentes identificados em Portugal, grande parte ocorreram após o ano 2000 (20,25\%, entre 2000 e 2010 e 54,43\% depois de 2010). Este comportamento está relacionado, principalmente, com a disponibilidade de informação estatística e técnica a partir do final dos anos 90 e início de 2000, mais do que pela maior ocorrência de eventos danosos e intensidade dos fluxos ferroviários em alguns territórios. Tendo em conta a semelhança com o dinamismo geral (Mundo e Europa), sublinham-se os acidentes isolados que, pelas consequências, marcam a evolução das ocorrências. Espacialmente, considerando a localização específica dos acidentes ferroviários (dimensão do número de mortes) e contabilização por concelho, verificamos que grande parte das ocorrências são aleatórias espacialmente, porém como uma forte correlação com territórios que integram ferrovias (fig. 8). Esta distribuição poderá estar associada a uma maior extensão/densidade da rede ferroviária e intensidade de fluxos, centrando as ocorrências em torno das duas áreas metropolitanas nacionais (acidentes mais recentes), ao longo das ferrovias do Norte, Beiras e Douro.

Por último, importa considerar os acidentes ferroviários em Portugal na perspetiva do tipo de ocorrência (fig. 9). Com efeito, dos 79 acidentes identificados, quase metade $(45,57 \%)$ foram atropelamentos. Contudo, verifica-se expressão também de tipo de ocorrências associadas à colisão por atravessamentolobstrução (25,32\%), descarrilamento (11,39\%) e colisão entre comboios (10,13\%). Em termos espaciais e de forma sumária, grande parte dos atropelamentos estáo associados à linha de caminho-de-ferro do Norte e à proximidade das duas áreas metropolitanas portu- 
TABELA IV - Lista de acidentes ferroviários em Portugal, com 3 mortes e mais (1865-2016).

TABLE V - List of railway accidents in Portugal, with 3 deaths and more (1865-2016).

\begin{tabular}{|c|c|c|c|c|c|c|c|c|}
\hline No & Ano & Dia & Mês & Localização & Concelho & Tipo de Acidente & $\begin{array}{l}\text { No }^{\circ} \\
\text { Feridos }\end{array}$ & $\begin{array}{l}\text { No }^{\circ} \\
\text { Mortos }\end{array}$ \\
\hline 1 & 1985 & 11 & Setembro & Alcafache & Mangualde & Colisão (entre comboios) & Vários & 150 \\
\hline 2 & 1964 & 26 & Julho & $\begin{array}{l}\text { Vila Nova de } \\
\text { Famalicáo }\end{array}$ & $\begin{array}{l}\text { Vila Nova de } \\
\text { Famalicáo }\end{array}$ & Descarrilamento & Vários & 102 \\
\hline 3 & 1964 & 26 & Julho & $\begin{array}{l}\text { Matosinhos } \\
\text { (Custóias) }\end{array}$ & Matosinhos & Colisāo (entre comboios) & Vários & 101 \\
\hline 4 & 1963 & 28 & Maio & $\begin{array}{l}\text { Lisboa (Cais do } \\
\text { Sodré) }\end{array}$ & Lisboa & $\begin{array}{l}\text { Barreira e Queda/colpaso de } \\
\text { ponte/túnel }\end{array}$ & Vários & 49 \\
\hline 5 & 1954 & 13 & Setembro & Odemira (Sabóia) & Odemira & Descarrilamento & 34 & 34 \\
\hline 6 & 1885 & 16 & Junho & $\begin{array}{l}\text { Vila Nova de Foz } \\
\text { Côa (Pocinho) }\end{array}$ & $\begin{array}{l}\text { Vila Nova de } \\
\text { Foz Côa }\end{array}$ & Fatores natuais (indiretos) & Vários & 29 \\
\hline 7 & 1952 & 31 & Março & Lisboa (Gibalta) & Lisboa & $\begin{array}{c}\text { Barreira e Queda/colpaso de } \\
\text { ponte/túnel }\end{array}$ & Vários & 19 \\
\hline 8 & 1984 & 26 & Abril & Paredes (Recarei) & Paredes & $\begin{array}{c}\text { Colisấo por atravessamento/ } \\
\text { obstruçáo }\end{array}$ & Vários & 17 \\
\hline 9 & 1986 & 5 & Maio & Póvoa de Santa Iria & $\begin{array}{l}\text { Vila Franca de } \\
\text { Xira }\end{array}$ & Colisâo (entre comboios) & Vários & 14 \\
\hline 10 & 1952 & 31 & Março & Cascais & Cascais & Fatores natuais (indiretos) & 38 & 10 \\
\hline 11 & 1921 & 9 & Novembro & $\begin{array}{l}\text { Setúbal (Figuei- } \\
\text { rinha) }\end{array}$ & Setúbal & Descarrilamento & 90 & 9 \\
\hline 12 & 2009 & 1 & Setembro & Baiāo & Baiăo & $\begin{array}{c}\text { Colisấo por atravessamento/ } \\
\text { obstruçáo }\end{array}$ & 1 & 6 \\
\hline 13 & 1997 & 8 & Novembro & Lagoa (Estômbar) & Lagoa & Colisâo (entre comboios) & 14 & 6 \\
\hline 14 & 1994 & 17 & Fevereiro & $\begin{array}{c}\text { Silves (São Marcos } \\
\text { da Serra) }\end{array}$ & Silves & $\begin{array}{c}\text { Colisão por atravessamento/ } \\
\text { obstruçấo }\end{array}$ & 2 & 6 \\
\hline 15 & 2009 & 1 & Setembro & $\begin{array}{l}\text { Baiăo (Ponte de } \\
\text { Quebradas) }\end{array}$ & Baiāo & $\begin{array}{l}\text { Colisấo por atravessamento/ } \\
\text { obstruçâo }\end{array}$ & 0 & 5 \\
\hline 16 & 1991 & 28 & Julho & Carregal do Sal & Carregal do Sal & $\begin{array}{c}\text { Colisấo por atravessamento/ } \\
\text { obstruçáo }\end{array}$ & 0 & 5 \\
\hline 17 & 2002 & 4 & Abril & Lousả & Lousã & Colisāo (entre comboios) & 4 & 5 \\
\hline 18 & 1919 & 10 & Setembro & Funchal (Monte) & Funchal & Explosâo/Incêndio/Eletrocussāo & Vários & 4 \\
\hline 19 & 2008 & 11 & Março & Leiria (Montijos) & Leiria & $\begin{array}{c}\text { Colisăo por atravessamento/ } \\
\text { obstruçáo }\end{array}$ & 0 & 4 \\
\hline 20 & 1949 & 26 & Setembro & Lisboa (Rossio) & Lisboa & Atropelamento & Vários & 4 \\
\hline
\end{tabular}

guesas (maiores fluxos, número de composiçôes em movimento e à preponderância das passagem de nível), sendo que as restantes tipologias (p.e. colisões por atravessamento/obstrução e a colisão entre comboios) estão mais dispersas e apresentam-se espacialmente de forma mais aleatória 


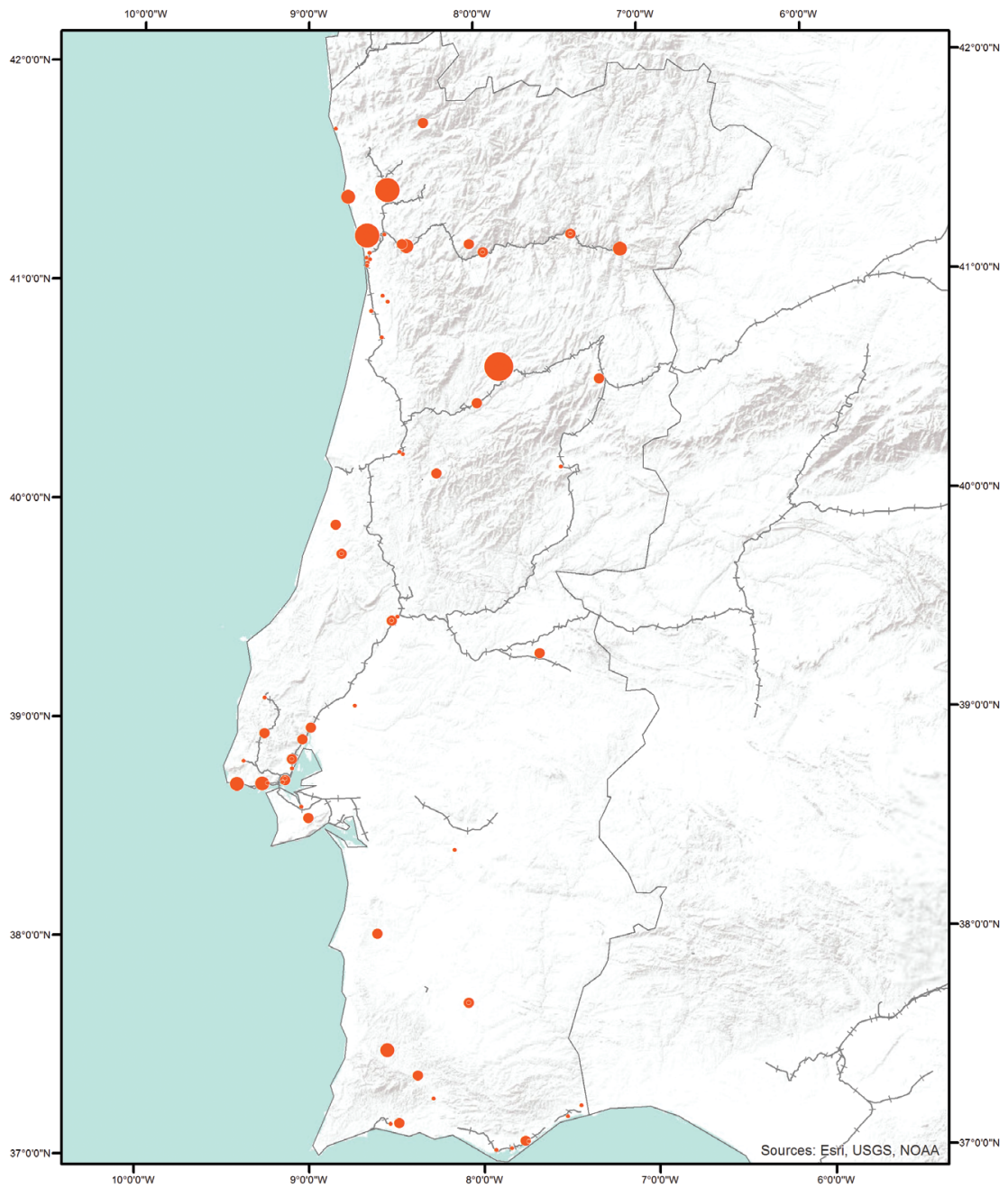

Legenda

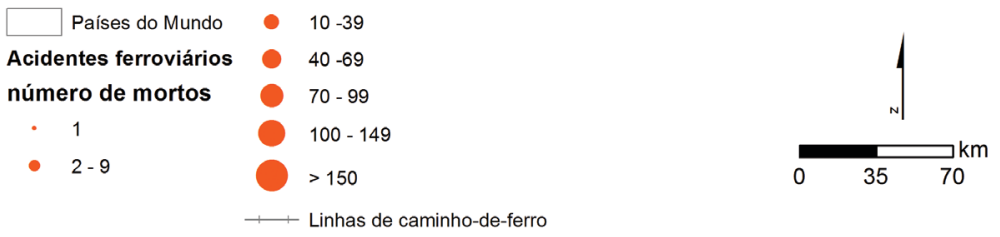

Fig. 8 - Acidentes ferroviários em Portugal por no de mortes (1865-2016).

Fig. 8 - Railway accidents in Portugal, by number of deaths (1865-2016). 


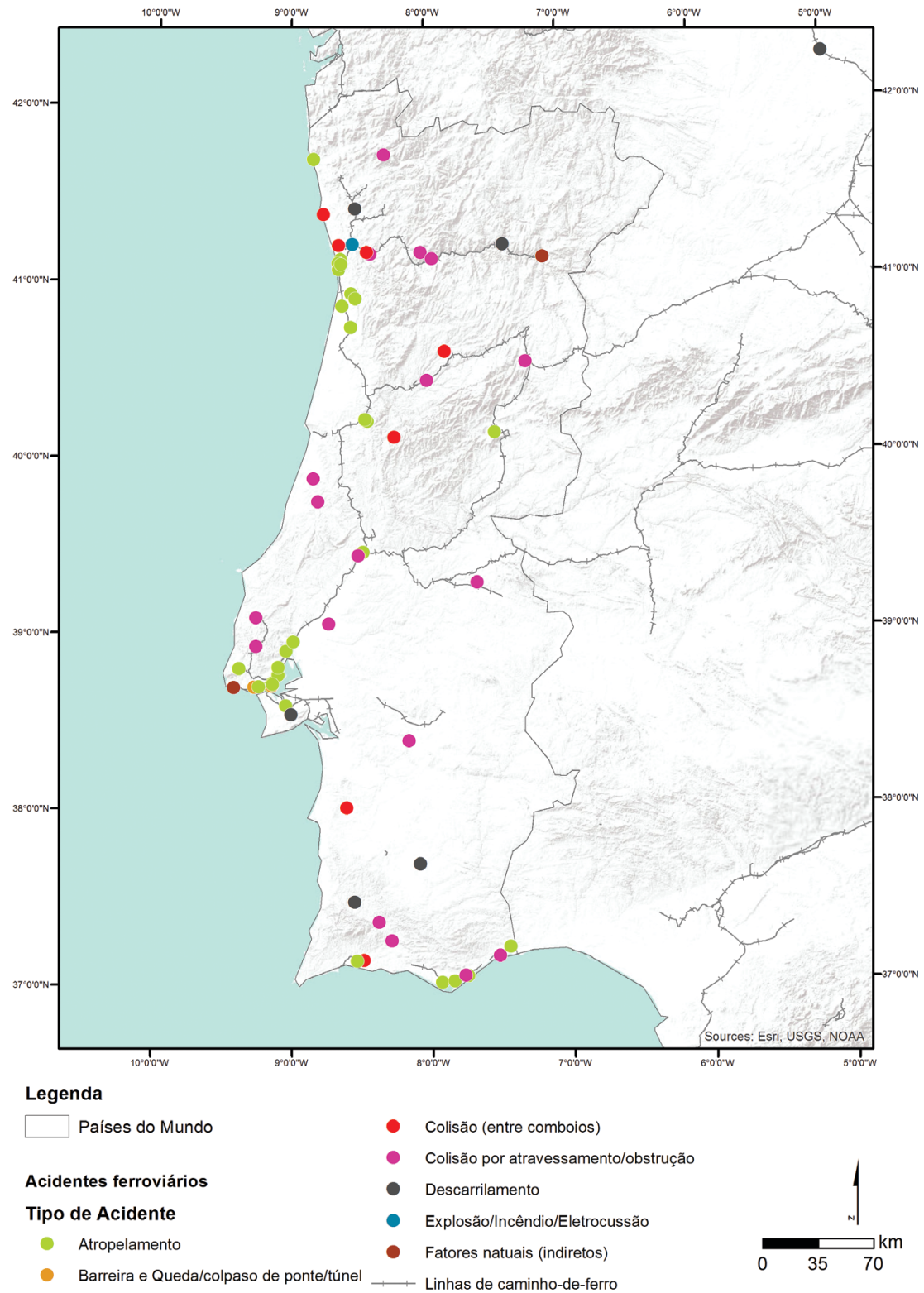

Fig. 9 - Acidentes ferroviários em Portugal por grande tipo de acidente (1865-2016). Fig. 9 - Railway accidents in Portugal, by major type of accident (1865-2016). 


\section{Notas finais}

A presente investigação tentou sistematizar o conceito de risco associado aos transportes ferroviários partindo da concetualização do acidente ferroviário quanto aos seus tipos, causas, localizaçáo e contexto de ocorrência. Tendo em conta a quase inexistência de investigação na temática, optou-se por um enquadramento dos acidentes ferroviários no sentido de identificar os elementos a considerar (antrópicos, técnicos, logísticos, territoriais, entre outros).

Independentemente da tentativa de criação de um contributo que constituísse uma abordagem inicial a este tipo (específico) de risco, foi a partir das diferentes ocorrências (acidentes) que se alicerçou a investigação. Em termos metodológicos, utilizaram-se várias fontes numa recolha (aberta) de acidentes, permitindo criar uma base de dados que identificou 429 acidentes ferroviários com mortes (que perfizeram um total de 22.440 mortes) e os seus atributos. Sublinha-se que, embora a matriz da investigação reflita uma análise estatística e espacial dos acidentes ferroviários a diferentes escalas, todos os comportamentos (ou tendências) discutidas estáo dependentes da informação (nem sempre completa) integrante da base de dados. Tendo em conta o caráter pontual e disperso, bem como a pluralidade de fontes tornou-se difícil definir uma trajetória de evolução dos acidentes e, $a$ posteriori, correlacioná-los com a sua localização e contexto territorial.

Em paralelo à evolução e comportamento espacial, existiu uma dificuldade no estabelecimento de padróes das ocorrências, muito devido à "dependência" da base de dados e à relatividade e caráter aleatório dos eventos. Sendo ocorrências que estão normalmente associadas a falhas humanas, técnicas e, em alguns casos, a fatores indiretos (naturais, por exemplo), são dificilmente previsíveis. Todavia, nas diferentes escalas analisadas, como seria expetável, existem fortes relaçóes das ocorrências com lógicas de localização de infraestruturas, ferrovias e terminais, intensidade e/ou densidade dos fluxos ferroviários. Por um lado, dada a maior informação e fluxos observa-se um maior número de acidentes em territórios mais desenvolvidos e urbanizados, por outro, nos territórios menos desenvolvidos, o número médio de mortes é bastante superior. Este reflexo (espacial) está diretamente relacionado com acidentes de grande dimensão que, independentemente 
de serem aleatórios e pontuais (quanto às causas, tipos e contextos), podem ser associados a espaços densamente povoados, com lacunas ao nível infraestrutural e tecnológico e, por vezes, com causas relacionadas com catástrofes (naturais).

Em suma, na perspetiva da análise dos acidentes ferroviários e tendo em conta a necessidade de melhor e mais informaçáo (que resulta de processos de prevenção, acompanhamento e monitorizaçáo dos acidentes ferroviários, bem como recolha in loco em contexto de catástrofe), observa-se uma centralidade da dimensão espacial e do contributo da Geografia para uma melhor compreensão das dinâmicas territoriais associadas. Independentemente de se tratar de um exercício analítico exploratório, poderá ser um importante ponto de partida para o conhecimento "espacializado e territorializado" dos acidentes ferroviários e uma alavanca para a definição de orientaçóes de prevenção de acidentes e gestáo de riscos associados a este tipo de transporte específico.

\section{Bibliografia}

ANPC - AUTORIDADE NACIONAL DE PROTEÇÃO CIVIL (2014). Avaliaçấo nacional do risco 2014. Lisboa.

Bavoux, J. (2005). Géographie des transports. Paris: Armand Colin.

Bibel, G. (2012). Train Wreck: The Forensics of Rail Disasters. EUA: Johns Hopkins University Press.

European Railway Agency (2014). Railway safety performance in the European Union. Bruxelas: European Union.

Haggett, P. (2001). Flows and Networks in Geography. Londres: Prentice Hall.

Haine, E. (2012). Railroad Wrecks. EUA: Cornwall Books,US.

Hall, S. (1992). Railway Disasters: Cause and Effect. EUA: The promotional reprint co. Ltd.

Knowles, R., Shaw, J. \& Docherty, I. (2007). Transport Geographies: Mobilities, Flows and Spaces. Londres: Wiley.

Lourenço, L. (2014). Risco, perigo e crise: trilogia de base na definiçấo de um modelo conceptualoperacional [Realidades e desafios na gestâo dos riscos: diálogo entre ciência e utilizadores NICIF]. Coimbra: Imprensa da Universidade de Coimbra, 61-72.

Richards, R. (2015). Railroad Accidents, Their Cause and Prevention. Londres: Leopold Classic Library.

Rodrigue, J., Comtois, C. \& Slack, B. (2013).The Geography of Transport Systems. Londres: Routledge.

Semmens, P. (1994). Railway Disasters of the World: Principal Passenger Train Accidents of the $20^{\text {th }}$ Century. EUA: Patrick Stephens Ltd.

Wolkowitch, M. (2004). Géographie des transports. Paris: Armand Colin. 


\section{Endereços electrónicos}

www.prociv.pt;

www.era.europa.eu

www.ine.pt

www.imtt.pt

www.wikipedia.org

www.ec.europa.eu/eurostat 